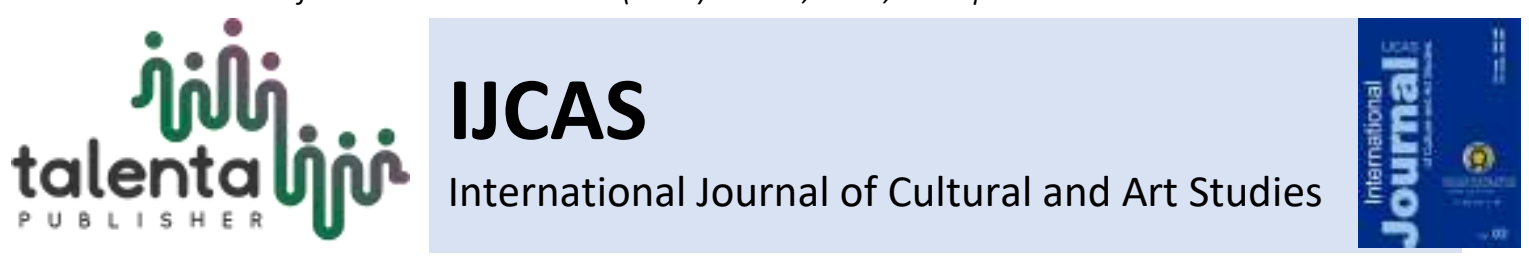

\title{
Low Malay Language As A Stimulant For Bahasa Indonesia Development
}

\author{
Novika Stri Wrihatni ${ }^{1 *}$, Hermina Sutami ${ }^{2}$ \\ ${ }^{1,2}$ Faculty of Humanities, Universitas Indonesia, Depok, Indonesia
}

\begin{abstract}
Bahasa Indonesia, which is the national and official language in Indonesia, is the result of the development of the High Malay Language (High Malay) in Riau. As the language used in the literature published by Balai Pustaka, the High Malay is respected as a language that is 'higher' than other languages used by the people of the Archipelago in the period before Indonesian independence in 1945. One of the 'lower' languages is Low Malay Language (Low Malay). Some literary works written in this language were printed by printing presses belonging to individuals consisting of indigenous and Chinese groups. The Low Malay style was used in writing romance to make the stories feel more "alive". This language of conversation should be counted as one type of language that contributes to the Indonesian language. The range of its uses is vast. However, with the development of politics in Indonesia, the Low Malay is once again marginalized. The language now only livesin conversation, yet it remains alive and developed along with the development of the times and the many influences of foreign languages on Indonesian language.
\end{abstract}

Keyword: Conversation, Low Malay, Marginalized, Romance Short Stories

Received 23 March 2019| Revised 20 April 2019| Accepted 28 April 2019

\section{Introduction}

Bahasa Indonesian as the language of unity was officially announced at the Youth Oath Event [Sumpah Pemuda] on October 28, 1928. However, efforts to carry out a periodization of the history of Indonesian Language have not been taken seriously and coordinated under the competent authorities [1]

This article will present factswhich willprove that, prior to the Youth Oath in 1928, the Low Malay had long been in coexistence with Malay to later form the Bahasa Indonesia. The fact that the language lives and is used as a social language can be interpreted that the language contributes to the livelihood of the language of conversation in Indonesian society at that time both for the indigenous and non-indigenous people . Moreover, Low Malay is not only present as an oral language, but it is also manifested in printed forms such as in newspapers, magazines and novels. So, at that time, in the community, dailies, magazines and novels were not only

\footnotetext{
${ }^{*}$ Corresponding author at: Faculty of Humanities, Universitas Indonesia, Depok, Indonesia, Jalan Prof. Dr. Selo Soemardjan Kampus Universitas Indonesia Depok, Indonesia

E-mail address: novika.stri@ui.ac.id
} 
written in High Malay (published by Balai Pustaka), but also in Low Malay (with the help of individual printing presses).

Chinese Malay - as part of Low Malay - uses many words of Hokkien, Batavian, and Dutch Language. It is no secret that these two languages are considered to be "inferior" to the Riau Malay Language which is labeled "High Malay". The striking difference between the other languages and High Malay language is in the field of lexicon, phonology, structure, and style of the language.

What sort of contribution has been given by Low Malay to stimulate Bahasa Indonesia development? Through this research, some facts obtained show that some of the fields mentioned previously helped develop the Bahasa Indonesia in its conversational variety.

This study uses data from magazines with Low Malay; these include the ones written in Chinese Malay published around 1867-1942. Research on romance stories that use both languages was examined by Professor Faizah S. Soenoto-Rivai. Given the many magazines that were published in that period, we chose them randomly. The topics were also chosen randomly. Through the temporary facts found, we intend to contribute ideas in building the history of the Bahasa Indonesia which is the theme of this seminar.

\section{Attention to Indonesian History}

Finding books on Bahasa Indonesia in the field of theoretical or applied linguistics is not difficult. Books about the history of the language, however, are not easy to find. Moreover, the discussion of the historical periodization of Bahasa Indonesia is still very "rare" or can even be said to be "nonexistent". The periodization of Indonesian literature, however, has been carried out decades ago. This begs the question of whether the history and periodization of the history of Bahasa Indonesia is considered as important as other language structures and subsystems, or it has never been thought about previously.

After all, Indonesian people possess national figures who are aware of the importance of the history of Indonesian language. Among those that deserve recognition - considering their significant works in the field - are Sutan Takdir Alisyahbana and Harimurti Kridalaksana. Dutch scholars like Teeuw and Steinhauer also gave their thoughts in this field.

Sutan Takdir Alisjahbana expressed his thoughts and opinions about the history of Bahasa Indonesia, its grammar and literatures through articles between 1932-1957. Harimurti Kridalaksana, an Indonesian linguist, in the past thirty years has also pioneered the history of Bahasa Indonesia, the origin of the name "Bahasa Indonesia", and the periodization of the 
Bahasa Indonesia. The following sections will discuss the prominent contributions of thought in the history of Bahasa Indonesia.

\subsection{Sutan Takdir Alisjahbana}

Dari Perjuangan dan Pertumbuhan Bahasa Indonesia [2] is a collection of articles from Sutan Takdir Alisjahbana in 1932-1957. In the book,Sutan Takdir showed a serious interest in the fields of language, literature and education. In addition, this figure not only contributed very valuable thoughts about the origins of Bahasa Indonesia, but also to what was called Low Malay and Chinese Malay. At first Sutan Takdir argued that the two languages were different languages.

In regard to Low Malay, which is considered to be "lower" than Bahasa Indonesia, which originated from High Malay, the following is Sutan Takdir's opinion as written in the book "Bahasa Indonesia" published by Pujangga Baru, in August 1933 (1978: 49):

"Sesungguhnya bahasa Melayu dan demikian juga bahasa Indonesia sebagai bahasa yang lain di muka bumi ini, berlainan menurut tempat kediaman orang yang memakainya (locale taalkringen), berlainan menurut golongan dalam pergaulan (familiale taalkringen) berlainan pula menurut pekerjaan dan kedudukan dalam pergaulan itu (sociale taalkringen).

Jadi kami hanya mengenal satu bahasa Indonesia yang mempunyai bermacam2 corak yang bergantung kepada ber-macam2 keadaan."

[Malay, Indonesian as well as other languages on this earth, differ according to the place of residence of the person who uses it (locale taalkringen), different according to groups in association (familiale taalkringen), and different according to a individual's work and position in that association (sociale taalkringen ). So we only know one Indonesian language that has a variety of styles that depend on various types of things.]

It turned out that in 1933 Sutan Takdir had seen a variant of Bahasa Indonesia according to its users such as locale taalkringen (regional dialect), sociale taalkringen and familiale taalkringen (social dialect). All three are Indonesian dialects.

Sutan Takdir also mentioned that Chinese Malay had apparently been abused and mocked in the 1920s, such as being called capcay language, racetu language, gado2 language, and several other names. His paper on that is entitled "Kedudukan Bahasa Melayu-Tionghoa" (The Position of Chinese-Malay Language) which was published by Pujangga Baru in October 1934 (1978: 57):

"Menurut pikiran saya dengan jalan demikian tiada mungkin timbul udara yang baik untuk menentukan tempatnya yang sebenarnya di tengah2 pergaulan di Indonesia ini. Dengan cuci maki dan hinaan tiada pernah orang mungkin menyelesaikan sesuatu soal.

Telah tibalah sekarang ketikanya menghadapi soal ini dengan tenang, tiada dipengaruhi oleh benci dan marah. Bahasa Melayu-Tionghoa telah berdiri dan berpengaruh di pergaulan 
Indonesia. Itu tiada dapat disangkal lagi. Meskipun bagaimana pendirian kita terhadap kepadanya, kita harus menerimanya seperti kenyataan yang tiada dapat ditolak lagi.

Apakah sebenarnya bahasa Melayu-Tionghoa? Bahasa Melayu Tionghoa ialah bahasa Melayu yang dipakai oleh bangsa Tionghoa."

[In my opinion, this is not a good way to determine the language's true place in society in Indonesia. Insults will never solve anything. Now is the time to face this matter calmly, without being influenced by hatred and anger. It is undeniable that Chinese Malay has been established and influential in the association of Indonesia. Despite how we stand against it, we must accept it as a reality that can no longer be rejected. What is actually a Chinese Malay language? The Chinese Malay is the Malay language used by Chinese people.]

The fact that Chinese Malay exists in society, according to Sutan Takdir, is something that must be accepted, whether we like it or not. In the same article, Sutan Takdir argues that Chinese Malay is not a branch of Malay or Indonesian, but serves as a means of communication among the people of Indonesia, so its validity must be recognized (1978: 59),

"Adapun kedudukan bahasa Melayu-Tionghoa sebagaicabang bahasa Indonesia itu amat ganjil. Berbeda dengan cabang2 bahasa Melayu atau bahasa Indonesia yang lain iapun dipakai sebagai bahasa perhubungan dan pergaulan antara penduduk di kepulauan ini yang berlain2an tempatnya, sehingga sebagai bahasa perhubungan ia boleh kita anggap berdiri disisi bahasa Indonesia umum. Jumlah buku, surat kabar dan majalah yang tertulis dalamnya amat besar, menyatakan pengaruhnya yang besar.

Kedudukan bahasa Melayu-Tionghoa sebagai bahasa perhubungan di sisi bahasa Indonesia itu harus kita anggap sebagai kedudukan yang sah di tengah masyarakat ini.”

[The position of Chinese Malay as a variety of Indonesian language is very peculiar. Unlike the varieties of Malay or other Indonesian languages, Chinese Malay is also used as a language of communication and association between the inhabitants of this archipelago; we may consider it as a language of communication which accompanies the Indonesian language. The number of books, newspapers, and magazines written in it is very extensive, and its influence is great. The position of Chinese Malay as a language of communication which accompanies the Indonesian language must be regarded as a legitimate in this society.]

Furthermore, Sutan Takdir expressed his appreciation based on his experience reading the article in the publication of the language (1978: 59):

Tidak ada suatu alasan juga kepada kita untuk memandangnya dengan ejekan dan cemooh. Tiada sesuai susunan katanya, gaya bahasanya, sebutan serta ejaannya dengan bahasa Indonesia adalah se-mata2 bergantung kepada kebiasaan yang mempunyai haknya dan aturannya sendiri. Bahasa yang dipercakapkan ditulis berpuluh ribu orang sejak ber-puluh2 tahun tiada dapat kita katakan dengan mudah saja bahasa yang kacau, bahasa yang tiada keruan. Saya yakin, bahwa perasaan yang se-tinggi2nya dan se-mulia2 mana sekalipun akan dapat dijelmakan dalam bahasa Melayu-Tionghoa, seperti dalam bahasa mana yang lain sekalipun di dunia ini. Dan orang yang terbuka hatinya untuk menerima keindahan, pasti ia akan dapat pula menerima keindahan itu dengan bahasa Melayu-Tionghoa. Saya sering membaca lukisan (misalnya tentang suatu pertandingan voetbal) yang hidup berjiwa dalam bahasa itu dengan nikmat dan bukan sekali dua timbul dalam hati saya perasaan iri: kalau kaum jurnalis Indonesia rata2 sehidup itu 
dan selancar itu memainkan bahasanya, alangkah lebih nikmatnya membaca surat kabar bahasa Indonesia.

Dalam beberapa hal jurnalis dan pengarang Melayu-Tionghoa harus dipuji tentang kecakapan mereka memakai bahasa yang tiada pernah dipelajari mereka dengan teliti, bahasa yang tiada mempunyai buku2 yang dapat dianggap sebagai ukuran bahasa yang indah.

[There is no reason for us to ridicule the language. Its incompatibility on the wording, style, designation, and spelling to the Indonesian language are due to habitual usewith its own rights and rules. The language spoken by tens of thousands of people for decades cannot be easily regarded as a chaotic and unclear language. I am convinced that even the highest and most noble feelings can be embodied in Chinese Malay language, such as in other languages in this world. People who open their hearts to receive beauty, surely will also be able to accept the beauty in Chinese Malay language. I often read paintings (for example about a voetbal match) that live spiritually in that language with pleasure, and once or twice, jealousy arise in my heart.If the Indonesian journalistm are that much alive and afluentin playing with the language, it would be very enjoyable to read newspaper in Indonesian language.

In some cases Chinese journalists and authors must be praised for their skills in using languages that they have never studied. A language in which no book exists which contain them that can be used to measure the beauty of the language.]

The following is his view on the consequences of recognizing the existence of Chinese Malay (1978: 60):

"Tetapi hal itu pasti akan berubah, barangkali boleh kita katakan telah mulai berubah. Keturunan yang muda lebih luas pendidikannya, ia tiada takut akan perkataann,malahan akan susunan kalimat yang ganjilpun. Bahasa Indonesia tiadalah akan rugi, apabila ia mengakui dengan jujur akan kedudukan bahasa Melayu-Tionghoa disisinya dalam pergaulan di negeri ini. Malahan oleh akuan itu boleh jadi derajatnya sendiri akan ternaik, sebab nyatalah betapa luasnya lingkungan bahasa Indonesia itu, betapa banyak corak dan warnanya."

[Tetapi hal itu pasti akan berubah, barangkali boleh kita katakan telah mulai berubah. Keturunan yang muda lebih luas pendidikannya, ia tiada takut akan perkataann,malahan akan susunan kalimat yang ganjilpun. Bahasa Indonesia tiadalah akan rugi, apabila ia mengakui dengan jujur akan kedudukan bahasa Melayu-Tionghoa disisinya dalam pergaulan di negeri ini. Malahan oleh akuan itu boleh jadi derajatnya sendiri akan ternaik, sebab nyatalah betapa luasnya lingkungan bahasa Indonesia itu, betapa banyak corak dan warnanya.]

The following quotation shows Sutan Takdir's attitude towards the position of Chinese Malay in the Archipelago (1978: 59):

"Nyatalah kepada kita, bahwa bahasa Malayu-Tionghoa itu sesuatu pengertian yang amat luas dan kabur. Yang terang hanyalah, bahwa ia sebuah cabang dari pada bahasa Melayu atau bahasa Indonesia. Dalam karangan ini selanjutnya dengan perkataan bahasa MelayuTionghoa itu saya maksud bahasa Melayu rendah yang kadang2 bercampur dengan perkataan Tionghoa, seperti dipakai oleh bangsa Tionghoa dan teristimewa golongan Baba di pulau Jawa dalam surat kabar, majalah dan buku2 mereka, yang amat banyak jumlahnya. 
[It is obvious to us that the Chinese Malay inhibits a very broad and vague understanding. It is clear that it is a branch of Malay or Indonesian language. In this essay, what I by Chinese Malay is similar to Low Malay. It sometimes mixes with Chinese words, as used by the Chinese, especially by the Baba group in Java in their many newspapers, magazines, and books.]

He also gave his opinion about Low Malay Language (1978: 59):

"Dengan bahasa Melayu rendah dimaksud di dalam karangan ini golongan bahasa Melayu yang bersahaja dan amat banyak menyalahi gramatika bahasa Melayu yang biasa disebut orang bahasa Melayu tinggi. Bahasa Melayu rendah itu berpusatbahasa Melayu Betawi. Dalam bahasa Indonesia umum yang sedang tumbuh sekarang ini kelihatan, bahasa Melayu tinggi mengambil beberapa elementen dari pada bahasa Melayu rendah."

[The Low Malay as intended in this essay is a modest group of Malay language which violates a lot of the grammatical structures of the Malay language known as High Malay. Low Malay is centered around the Batavian Malay language. To sum up, the growth of Indonesian language is now visible; High Malay takes several elements from Low Malay.]

From the above opinion, it can be concluded that both Low Malay and Chinese Malay are variants of the Bahasa Indonesia. It is fortunate that around a century ago we had a broadminded figure who respected diversity and the reality of it in society. This thought of Sutan Takdir was used as the rationale for this paper.

\subsection{Harimurti Kridalaksana}

This scholar is a figure and expert in the Bahasa Indonesia who is younger than Sutan Takdir. He paid great attention to the history of Bahasa Indonesia and has produced a number of works on the periodization of Bahasa Indonesia which had not been carried out by other Bahasa Indonesia historical figures.

One thing that needs to be pointed out is that on his initiative a number of documents about the history of Indonesian have been examined. From the result, it was found that the originator of the name "Bahasa Indonesia" as the language of the unity of the Indonesian nation was M. Tabrani. The naming took place at a meeting of the members of the First Youth Congress Committee on May 2, 1926. [3]

Unlike Sutan Takdir, whose articles were mostly about the history of Indonesian, written before Indonesian independence in 1945, Harimurti worked in this era of independence. The difference in the topic of the conversation was clear. Sutan Takdir talked about the relationship between Malay and Indonesian and the existence of Low Malay which dominated the publishing world of newspapers, magazines, and novels at the time which worried Indonesian patriotic figures at that time. In Harimurti's era, the second problem (the existence of Low Malay) was not the main problem, considering that there were no schools that taught Low Malay and the magazine 
published in that language did not dominate Indonesian publishing. It could be said that its existence was not "as threatening" as in Sutan Takdir's era. Moreover, after the government of former President Suharto issued a ban on the publication of Low Malay newspapers, such as Star Weekly, in 1966, since then Low Malay has been "written off" and only spoken by groups aged 40-50 years and above.

Even so, the discussion on the history of the Bahasa Indonesia, which is not or has not been the concern of language and non-language experts of today's young generation, continues to be carried out by Harimurti.

The quotation below shows Harimurti trying to clarify the origins of Low Malay. If it is not a branch of Malay, as Sutan Takdir said, then where did it come from? The answer can be found in the article titled "Mitos tentang terjadinya Bahasa Indonesia dari sebuah kreol" (Myths about the occurrence of Indonesian language from a creole) [4]:

"Di samping bahasa Melayu yang "full-fledged" [bahasa Melayu secara substansiil sudah merupakan bahasa penuh (full-fledged language) dan menjadi bahasa ibu dari masyarakat yang tinggal di wilayah Sumatra sebelah timur, Riau, dan Kalimantan, dan sudah mempunyai kesusastraan yang berkembang] itu terdapat pula variasi lain yang disebut bahasa Melayu Pasar yang dipergunakan oleh pedagang-pedagang Tionghoa dan oleh orang Belanda dalam berbicara dengan orang yang dijajahnya. Bahasa melayu Pasar jelas merupakan pijin.

[In addition to the 'full-fledged' Malay language, (which is also the mother tongue of the people living in the eastern Sumatra region, Riau, and Kalimantan, and has a very developed literature), there is also another variation called the Market Malay language which is used by Chinese traders and by the Dutch in talking to people they colonize. The Market Malay language is clearly a pidgin.]

From the quotation above, what is meant by Market Malay is none other than Low Malay, because it is used as a tool of social communication in brief contacts such as in trading among people of different languages[7].This trading language uses words from the Hokkien, Dutch, and local language vocabulary such as Batavian with a "facilitated" structure. Note the structure of one of the sentences in Sin Po newspaper of September 8, 1923, from the article "Bom Mengamoek" with the comparison in Indonesian language:

"Tentoe sadja ini kadjadian tiada bisa tiada diperhatiken oleh pamerentah, jang poendi ini kali oendjoek iapoenja perasahan tjoeriga jang tiada berdasar pada bangsa Tionghoa" (Bahasa Melayu Rendah)

"Tentu saja kejadian ini mendapat perhatian pemerintah yang kali ini pun menunjukkan rasa curiganya yang tak mendasar terhadap bangsa Tionghoa”(Bahasa Indonesia) 
It is not easy to understand what is meant by "facilitated", it seems more appropriate to call it "adjusted" to the structure of their mother tongue. The use of Dutch, Hokkien, English and local language vocabulary is also found in the following:

"En toch ada bebrapa orang jang masi bisa bilang, voetbal Tionghoa sekarang ada di dalem kamadjoean!" ('Kaädahan voetbal Tionghoa di Batavia", Sin Po, Saptoe 26 Mei 1923)

"En toen kaloe soeda djadi kombali hokhia, apa satoe istri haroes berboeat sakerasnja mendjaga dan control tingka-lakonja sang laki? ('Tjara bagimana membikin soeami mendjadi djinek?", Keng Po, 6 Juli 1935)

\footnotetext{
"Apa itoe?" Ini soeara adalah soeranja hoedjin Gouw Siang Bok jang baroe keloear dari kamar mandi. Kwie Hiang dan sianseng Gouw Siang Bok seperti kesima, hingga ia djadi bengong sementara lamanja. ('Nona Kwie Hiang", Kong Hwee Po, 6 September 1923)
}

The Market Malay which was originally only used for trade communication purposes eventually became the mother tongue of Chinese descent in the archipelago. Thus, it starts with the language's pidgin to turn into a creole. This symptom is seen by Harimurti as a positive symptom in the development of Bahasa Indonesia [4]

"Adanya pijin dan kreol yang berdasar bahasa Melayu ("Malay based pidgins and creoles") dan adanya dialek-dialek regional itu memudahkan penerimaan, penumbuhan, dan penyebaran bahasa Indonesia sebagai bahasa nasional."

[The existence of pidgin and creole based on Malay (Malay-based pidgins and creoles) and the existence of regional dialects that facilitate the acceptance, growth, and dissemination of Indonesian as a national language.]

Through this statement, Harimurti and Sutan Takdir had more or less the same views about the existence and contribution of Low Malay to the Bahasa Indonesia. The following is presented the characteristics of Low Malay as an Indonesian variant of conversational variety.

\section{Low Malay}

Broadly speaking, the existence of Low Malay in the history of Bahasa Indonesia can be figured as follows.

Figure 1. Low Malay in the History of Bahasa Indonesia 


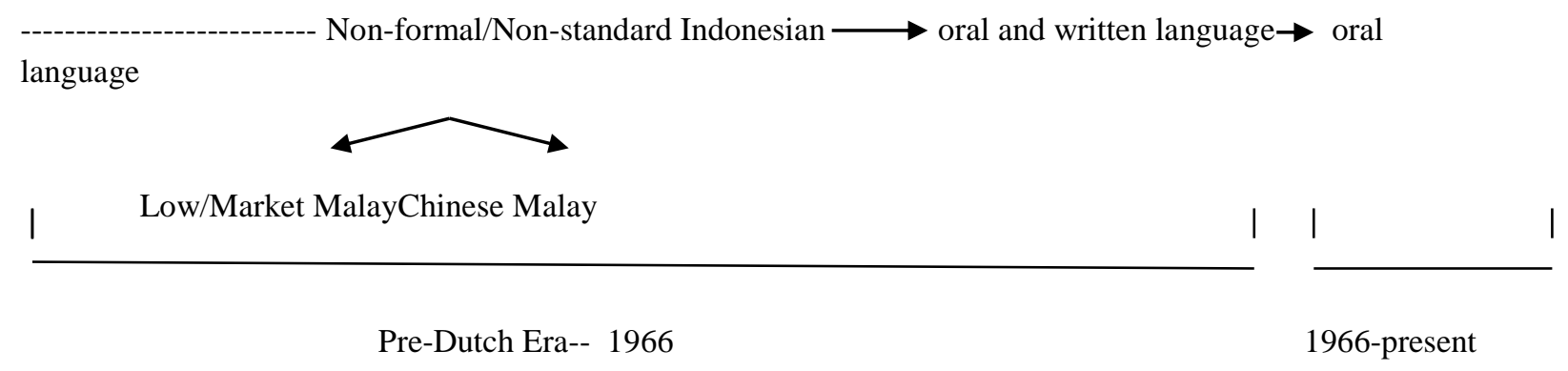

The figure above shows that Low Malay did not originate from High Malay; it became a nonformal language used as an oral and written language until 1966. From 1966 to the present, the language is only used in spoken.

Its contributions to the social characteristics of Bahasa Indonesia are based on two aspects, namely nonlinguistic and linguistic. Through this aspect, based on data from 1867-1942, the characteristics of Low Malay as a variant of Indonesian in the Dutch era will be obtained. The nonlinguistic aspect is related to the diversity of the topic of the article, while the linguistic aspect consists of linguistic fields such as phonology, syntax, and language style.

\subsection{Nonlinguistic Aspect}

From the nonlinguistic aspects, various types of articles with various rubrics are obtained, such as politics, education, social, ethnics, sports, health, jokes, advertising, and so on. The types of rubrics presented below can still be increased.

\section{(A) Politics}

(1) Bagelener, 19 Maret 1910, "Turki pada masa ini”, Medan Prijaji, Batavia.

(2) --, 26 Mei 1923, “Gerakan boycot”, Sin Po, Batavia.

(3) --, 8 September 1923, "Bom mengamoek", Sin Po, Batavia.

(4) --, 8 September 1923, "Kantoor voor Chineesche zaken", Sin Po, Batavia.

(5) --, 8 September 1923, "Vivat foc-trott dal alcohol", Sin Po, Batavia.

(6) --, 6 Juli 1935, ”Sama rata-sama rasa", Keng Po, Batavia.

(7) I. Lejak, Juni 1027, ”Maoe Kemana?”, Soerja Kanta, Singaradja. 
(8) --, 6 September 1923, "Pridatonja Sri Ratoe dalem garedja Nieuwe Kerk koetika ia bersoempah", Kong Hwee Po, Batavia.

(B) Education

(1) --, 26 Mei 1923, "Pladjaran boeat anak Tionghoa", Sin Po, 26 Mei 1923

(2) --, 9 October 1867, "He bapa saya maoe bli soerat kabar", Bianglala, no 3

(3) --, 9 October 1867, "Akan hal Hindoestan", Bianglala, no 3.

(C) Sports

(1) O.T.H, 26 Mei 1923, "Kaädahan voetbal Tionghoa di Batavia", Sin Po, Batavia.

(D) Economy

(1) Hauw San Liang, 26 Mei 1923, "Berladjar sendiri dubbel-Boekhouden”, Sin Po, Batavia.

(E) Culture

(1) --, Juni 1927, ”Adat kita”, Surya Kanta, Singaradja.

(F) Humour

(1) --, 26 Mei 1923, "Sala mengerti”, Keng Po, Batavia.

(2) --, 26 Mei 1923, “Kaga enak”, Keng Po, Batavia.

(3) --, 26 Mei 1923, "Betoel Tjialat”, Keng Po, Batavia.

(4) --, 14 April 1923, "Gandjaran plesir Tjapgomeh”, Sin Po, Batavia

(G) Advertising

(1) Juni 1927, "Loterij Oewang Vincentius", Surya Kanta, Singaradja.

(2) Juni 1927, ’Horlodji kantong", Surya Kanta, Singaradja.

(3) 26 Mei 1923, “Tebakan Bedak Virgin”, Keng Po, Batavia.

(4) 9 Juni 1923, "Lourdes, Mineraalwater fabriek", Sin Po, Batavia.

(5) 12 Juni 1923, "Bagelensche Ronde Tafelbeschuit njang soedah terkenal dimanamana tempat, paling baik” Kong Hwee Po. 
(6) 15 September 1923, "Di-mana toean maoe beli topi? Bagoes moerah dan menjenangken hati?"

(H) Security

(1) --, Juni 1927, "Bahaja jang hampir menimpa Poenggawa Soekasada", Surya Kanta, Singaradja.

(I) Beauty

(1) --, 26 Mei 1923, "Bagimana kita haroes berdjalan”, Keng Po, Batavia.

(J) Family

(1) --, 12 Juni 1923, "Toean Lim Giauw Goan dengen poetoesnja ia poenja tali pernikahan", Kong Hwee Po, Batavia.

(K) Health

(1) --, 19 October 1910, "Bahaja poeroe sembilik", Pantjaran Warta

\subsection{Linguistic Aspect}

The linguistic characteristics of Malay Language are observable in the fields of phonology, syntax, and language style. The following is from the field of phonology.

(A) Phonology

(1) Phonemic Addition

The addition of phoneme The The elimination The The $\mathrm{h} / \mathrm{elimination}$
phoneme $/ \mathrm{h} /$$\quad \begin{array}{ll}\text { addition } \\ \text { of }\end{array}$ phoneme phoneme/k/ /i/

\begin{tabular}{|c|c|c|c|}
\hline $\begin{array}{l}\text { keadahan, perasahanan, } \\
\text { kabangsahanan, kekajahan, } \\
\text { pertjobahan, katjintahan, } \\
\text { tjiptahan, kapertjajahan, } \\
\text { di permoelahannja, } \\
\text { kadjadihan, perbedahan }\end{array}$ & $\begin{array}{l}\text { liat, meliat, } \\
\text { kaliatan, soeda, } \\
\text { taoe, abis, } \\
\text { ampir, taon, } \\
\text { soenggoe, taro, } \\
\text { sekola, beroba, } \\
\text { roemanja, } \\
\text { penoe, tegoe, } \\
\text { kasi, ilang, } \\
\text { roeboe, kasian, } \\
\text { lebi, }\end{array}$ & $\begin{array}{l}\text { printah, bri, } \\
\text { bebrapa, negri, } \\
\text { pladjaran,blakang }\end{array}$ & heibat tida \\
\hline
\end{tabular}


pengidoepan,

(2) Phonemic Substitution

\begin{tabular}{|c|c|c|c|c|}
\hline $\begin{array}{l}\text { /a/ is substituted } \\
\text { with /e/, /i/, [ai] }\end{array}$ & $\begin{array}{l}\text { /e/ is substituted } \\
\text { with } / a / \text {, }\end{array}$ & $\begin{array}{l}\text { /e/ is substituted } \\
\text { with } / \mathrm{o} /\end{array}$ & $\begin{array}{l}/ \mathrm{u} / \text { is substituted } \\
\text { with } / \mathrm{o} /\end{array}$ & $\begin{array}{l}\text { /i/ is substituted } \\
\text { with /e/ }\end{array}$ \\
\hline $\begin{array}{l}\text { dengen, tanem, } \\
\text { harep, padjek, } \\
\text { dapet, matjem, } \\
\text { dalem, hadepan, } \\
\text { saolah-olah, aken }\end{array}$ & $\begin{array}{l}\text { kalakoean, } \\
\text { karoewan, } \\
\text { kabangsahan, } \\
\text { bagitoe, kadjadian, }\end{array}$ & kombali, & tahon & laen, baek \\
\hline
\end{tabular}

(3) Diphtong Substitution

Diphtong [ai] is replaced with [i] or [e]

\begin{tabular}{l}
\hline bagimana \\
\hline pake, rame, sampe, laen
\end{tabular}

(4) Multi-phonemic Substitution

Malay Indonesian Language

sakean, belon, marika, semingkin $\quad$ sekian, belum, mereka, semakin

(5) The Appearance of Semivocal [w] with or without additional vocal

Bahasa Melayu Bahasa Indonesia

karoewan, koewat, boewang,toewa, $\quad$ keruan, kuat, buang, tua, uang, tuan, atau oewang, toewan, atawa

(6) Syllabic Addition

Bahasa Melayu Bahasa Indonesia

rahajat, bahoewa rakyat, bahwa

According to its status as a non-standard language, the characteristics mentioned above are not consistent. There are those which have two forms such as taon and tahon, plajaranandpelajaran, and boeang and boewang. This inconsistency is mainly seen in two or 
more syllabic words with the sound $[u]$ at the end of its first syllable which is followed by the sound of [a] in the next, for example, in Boewang and Boeang, and Toewa and Toea. However, there is an exception to this as in the word doea; the word does not change into doewa.

The other categories are in phoneme /a/ in suffixes -kan which becomes -ken (such as in teroesken, perhatiken, anterken), phoneme /e/ at the prefix se-which becomes sa- (such as in sabaliknja and sasoedanja), and in prepositions ke- into ka- (kamana, ka satoe kantoor, kaindjek-indjek)

(B) Morphology

The morphological characteristics of the Malay language used in the Betawi region are characterized by the use of suffix -in in salingkoein (basic word: selingkuh [cheating]), and tondjolin (basic word: tonjol [bulge]), and suffix -an in enak-enakan.

(C) Syntax

The language's structural characteristics have been fully disclosed by Harimurti (2002). In this article, these features will be presented again with examples. In addition, several features which have not been included previously will be added.

(1) The ergative form which uses the words kena and dapet [get] (Bahasa Indonesia: in $+\mathrm{V}$, ter $+\mathrm{V})$

1. Dan baroe ini di tengah-tengah pesta djoebilem orang kombali melempar bom hingga bebrapa penonton, antara siapa ada bebrapa orang Tionghoa, telah dapet loeka. ("Bom Mengamoek", Sin Po, September 1923).

2. Sebab saja ada dapet batja satoe boekoe jang menoetoerken bebrapa pergerakan badan boeat bikin kita poenja tindakan djadi bagoes. ("Bagimana kita haroes berdjalan?", Keng Po, 6 Juli 1935)

3. Soeami jang "takoet bini" terang sekali ada lemah, males, atawa pikirannja koerang waras, dan kena dipengaroehin oleh itoe inferiority complex yang djahat. ("Bagimana membikin soeami mendjadi djinek?", Keng Po, 6 Jui 1935)

(2) The causative form using $\mathrm{V}+$ in (Indonesian language: $\mathrm{V}+k a n, \mathrm{~V}+i$ ), and bikin [make] $+\mathrm{V}$ (Indonesian language: $M e+\mathrm{V}+k a n)$, and kasi[give] $+\mathrm{V}$ (Indonesian language: beri[give] $+\mathrm{V}$ )

4. Pertama dia moesti berdiri djedjek dengen toelang blakang jang dilempengken sabrapa bisa; zonder beratin badannja ka depan [...] ("Bagimana kita haroes berdjalan?”, Keng Po, 6 Juli 1935) 
5. Banjak orang toewa kasi masoek sang anak dalem K.W.S. jang sabenernja moesti dikasi pladjaran dalem M.U.L.O. ("Organisatie dari perladjaran Olanda di Hindia", SinPo, 8 September 1923)

6. Ini kantoor didiriken oleh pamerentah Olanda, tetapi orang moesti sangsiken apa ini kantoor tiada bikin samingkin renggang perhoeboengan antara pemerentah dan bangsa Tionghoa [...] ("Bom Mengamoek", Sin Po, 8 September 1923)

(3) The possessive form using the word punya [got]

7. Bilah kita bandingken, kita orang poenja kaädahan dengen keaädahan voetbal dari laen bangsa disini, brangkali itoe kasedihan bisah bikin aer-mata mengoetjoer. ("Kaädahan voetbal Tionghoa di batavia", Sin Po, 26 Mei 1923)

8. Orang-orang Olanda dan Duitsch sering bertentangan pikiran lantaran masingmasing anggep iaorang poenja bangsa jang dapetken ilmoe menjitak jang loear biasa pentingnja boeat kamadjoean doenia. ("Pendapetan-pendapetan dari bangsa Tionghoa", Sin Po, 28 April 1923)

(4) Nominal phrases with ini [this] or itu [that] attribute

9. Swee Siauw (pada adenja iapoenja toendangan): Apa loe mara kaloe goea kawin sama entji Ennie?

Adenja Ennie: Kaga. Papa kemaren bilang: achirnja si Ennie dapet djoega toendangan, maskipoen ini toendangan kaliatannja tolol!

(“Kaga enak”, Keng Po, 6 Juli 1935)

10. Ada orang jang membri kabar, bahwa waktoe perkara dimadjoekan itoe wedono soeda brenti dengen pensioen. (" Turki pada masa ini", Medan Prijaji, Saptoe 19 Maart 1910)

(5) The sequence of verbs in a sentence which reflects the order of actions (iconicity)

11. Politie dari sectie III denger lantes telah koendjoengin itu tempat (Kebangoenan, 3 July 1938)

12. Rusland achirnja aken brenti boeat tjoba desek kaloear negri-negri Barat dari Berlijn (Keng Po, 29 September 1949). 
(6) The verb ada [similar to exist] as markers of durative aspects

13. Pertanjahan terseboet ada dimadjoekan oleh Miss S.N.Khouw, Buitenzorg. ("Bagimana membikin soeami mendjadi djinek?", Keng Po, 6 Jui 1935)

14. Kendati satoe pendjahat jang paling besar, kaloe satoe kali ia soeda bertobat, ia ada lebih baek dari satoe padri," kenapa itoe anggepan masi sadja koekoeh di dalem sanoebarinja orang prampoean? ("Bagimana membikin soeami mendjadi djinek?”, Keng Po, 6 Jui 1935)

(7) Verbal clause with the word punya [has] and its possessive noun phrase -nya

15. Ini kantoor didiriken oleh pamerentah Olanda, tetapi orang moesti sangsiken apa ini kantoor tiada bikin samingkin renggang perhoeboengan antara pamerentah dan bangsa Tionghoa, hingga ia boekan djaga tetapi djoestroe sebaliknja bikin roesak kapentingan ia poenja pamerentah sendiri [...] ("Bom Mengamoek", Sin Po, 8 September 1923)

16. Soenggoe kasian! Kiok Hoa soenggoe haroes dikasiannin! Ia soeda korbanken iapoenja soeami, kadoedoekan [...] ('Dames Rubriek", Keng Po, 6 Juli 1935)

(8) -nya as an explicit means of possessiveness

17. Tadinja rahajat Boemipoetra selaloe djongkok di hadepannja satoe ambtenaarOlanda [...] ("Bom Mengamoek", Sin Po, 8 September 1923)

18. Sebab roemanja doea orang Tionghoa digledah dan [...]("Bom Mengamoek", Sin Po, 8 September 1923)

(D) Language style

The style of language used is very straightforward; it makes the sentences of Low Malay feel "alive". Such language style, also known as the newspaper style, is not very different from the current newspapers such as the Lampu Merah, Pos Kota and the like.

\section{Conclusion}

Through the facts revealed from data acquired from newspapers and magazines published in 1867-1942, it seems that the existence of Low Malay needs to be taken into account in the periodization of the history of the Bahasa Indonesia. Even though this language is not a standard 
language, its temporal range, location, user, usage is very broad. In fact, Sanoesi Pane, a wellknown author who was a member of the First Bahasa Indonesia Congress committee (Sala, June 25-8, 1938) who never used this language in his writing, actually led Kebangoenan magazine which uses Low Malay. This is proof of the "efficacy" of the language as a means of communication with the common people who do not necessarily understand the contents of the novels in High Malay or Bahasa Indonesia.

Thus, the existence of Low Malay contributes to the historical social characteristics of Bahasa Indonesia as an inseparable part of High Malay or Bahasa Indonesia. Its reach is so broad; it reaches the people in general, not just certain groups. It may be said that this language is the language of the Indonesian people, even though it is not standard.

\section{REFERENCES}

[1] H. Kridalaksana, "From Low Malay to Standard Malay" paper on Konperensi Internasional ISMIL, Leiden, 2002.

[2] S.T. Alisjahbana, Sutan Takdir. (1975). Dari Perjuangan Pertumbuhan Bahasa Indonesia. Jakarta. PT Dian Rakyat.

[3] H. Kridalaksana, Masa-masa Awal Bahasa Indonesia, Depok: Laboratorium Leksikologi dan Leksikografi Fakultas Ilmu Pengetahuan Budaya Universitas Indonesia, 2009.

[4] H. Kridalaksana, "Mitos tentang terjadinya Bahasa Indonesia" in Harimurti Kridalaksana (ed.), Masa Lampau Bahasa Indonesia: sebuah bunga rampai, Yogyakarta, Penerbit Kanisius, 175-179, 1991.

[5] S. Effendi \& Zulkarnaen, Ikhtisar Sejarah Bahasa Indonesia, Jakarta: Lembaga Bahasa Nasional Direktorat Jenderal Kebudayaan Departemen P dan K, 1972.

[6] U. Junus, Sedjarah dan Perkembangan Kearah Bahasa Indonesia dan Bahasa Indonesia, Jakarta: Bhratara, 1969.

[7] H. Steinhauaer, "Tentang Sejarah Bahasa Indonesia" in Harimurti Kridalaksana (ed.), Masa Lampau Bahasa Indonesia: sebuah Bunga Rampai. Yogyakarta, Penerbit Kanisius, 195-218, 1991. 